\title{
Pancreatic pseudocyst with fistula to the dilated common bile duct: Mimmicking choledocal cyst?
}

\author{
Nari Gustavo, Lopez Alesio, Romero Tanus Lorna, De Elias Eugenia, and Lopez Flavia \\ General Surgery Service, Tránsito Cáceres de Allende Hospital, Córdoba, Argentina
}

\begin{abstract}
We present a rare case of a fistula between a pancreatic pseudocyst and the bile duct with saccular dilatation that appeared to be a type I choledocal cyst. There are only 19 described cases in the consulted bibliography. The patient was studied with an ultrasound, CT and MRCP and later surgically intervened. A resection was performed of the extrahepatic biliary and hepaticojejunostomy. There was a subsequent good evolution. (Ann Hepatobiliary Pancreat Surg 2021;25:155-159)
\end{abstract}

Key Words: Pancreatic; Pseudocyst; Fistula; Bile duct

\section{INTRODUCTION}

The formation of a pancreatic pseudocyst originates from inflammation or trauma of the pancreatic gland, ${ }^{1-6}$ this lesion can establish a fistula with neighboring organs within which the stomach, duodenum and colon are the most frequent while less frequent would be within the esophagus and very rarely in the common bile duct, we have only found 19 cases in the bibliographic search. ${ }^{1-16}$ These fistulas usually cause complications such as: pain, cholangitis and hemorrhages that can lead to the death of the patient.

The aim of this communication is to contribute a new case with the particularity that the bile duct presented cystic dilation and to review the different therapeutic alternatives for this rare condition.

\section{CASE}

A 60 year old male patient was admitted with 20 day progressive jaundice, associated with pruritus, choluria and hypocolia. Patient reports mild and nonspecific pain in the right hypochondrium. Presented episodes of nausea and vomiting. Weight loss of $12 \mathrm{~kg}$ in 3 months.

As of his surgical history, he refers to a right nephrec- tomy because of a tumor 1 year ago in another hospital. A year and a half ago he reported an episode of severe acute pancreatitis of probably lithiasic origin in another institution (previous studies could not be retrieved).

Admission laboratory: leukocytosis: 16300, PRC: $105 \mathrm{mg} /$ dl. Total bilirubinemia: $15 \mathrm{mg} / \mathrm{dl}$. Direct bilirubin: $13 \mathrm{mg} / \mathrm{dl}$. Alkaline phosphatase: 343 UI/L. GGT: 176 UI/L. GOT: 51 U/ L. GPT: $57 \mathrm{U} / \mathrm{L}$.

Ultrasound reports a dilated intrahepatic bile duct, 11 mm common bile duct. Gallbladder with thickened walls with lithiasis inside. Cystic and heterogeneous collection $(74 \times 80 \mathrm{~mm})$ in head and body of pancreas. Duct of Wirsung dilation. CT: enlarged pancreas, 74-mm cystic image in the head of páncreas. Marked Wirsung dilatation (13$\mathrm{mm})$. Important dilatation of the extrahepatic bile duct with a $36 \mathrm{~mm}$ of diameter in the common bile duct and lithiasis in its interior. Cholelithiasis. Normal chest CT.

Nuclear magnetic resonance cholangiography (MRCP): dilatation of the extrahepatic bile duct. Pancreatic pseudocyst with fistula to the main bile duct (Figs. 1-3)?

A percutaneous drainage of the bile duct was decided through which a cholangiography was performed, which reaffirmed the findings of the MRCP and did not objectively progress the contrast medium towards the Duct of

Received: June 22, 2020; Revised: July 11, 2020; Accepted: July 12, 2020

Corresponding author: Gustavo Nari

General Surgery Service, Tránsito Cáceres de Allende Hospital, Buchardo 1250-5000, Córdoba, Argentina Tel: +54-351-2181218, Fax: +54-351-4342403, E-mail: gusnari@hotmail.com

Copyright (C) 2021 by The Korean Association of Hepato-Biliary-Pancreatic Surgery

This is an Open Access article distributed under the terms of the Creative Commons Attribution Non-Commercial License (http://creativecommons.org/ licenses/by-nc/4.0) which permits unrestricted non-commercial use, distribution, and reproduction in any medium, provided the original work is properly cited. Annals of Hepato-Biliary-Pancreatic Surgery • pISSN: 2508-5778 - elSSN: 2508-5859 

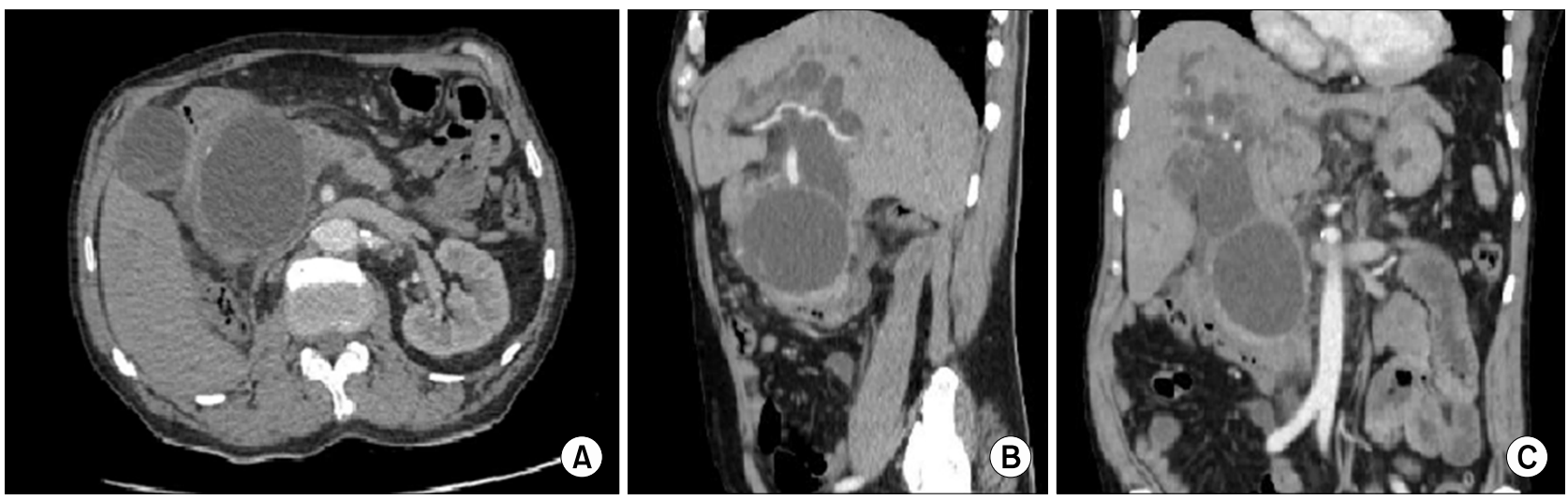

Fig. 1. CT showing the pseudocyst and the great dilatation of the bile ducts.

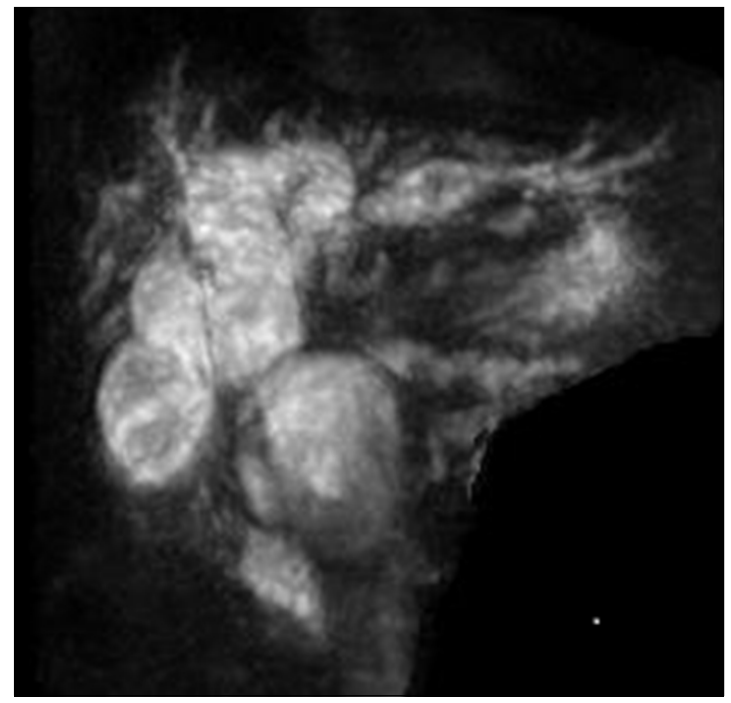

Fig. 2. MRCP, pseudocyst is comunicated and compressing the bile duct.

Wirsung, bile was sent for amylase dosing, reporting a value greater than 25,000 U/L. CEA markers: $3.0 \mathrm{ng} / \mathrm{ml}$. CA 19.9: $88 \mathrm{U} / \mathrm{ml}$. CA 125: $16 \mathrm{U} / \mathrm{ml}$. Alpha fetoprotein: $2.65 \mathrm{ng} / \mathrm{ml}$.

With the diagnosis of a common bile duct cyst fistulized into a pancreatic pseudocyst without communication with the duct of Wirsung, surgical conduct was decided, the findings of which are: hypoplastic gallbladder with a stone, increased duodenal-pancreatic vascular comb, large saccular dilatation of the extrahepatic bile duct and thin/ transparent walls.

Cholecystectomy and intraoperative cholangiography were performed, showing saccular dilatation of the extrahepatic bile duct and dilatation of the intrahepatic bile duct. As a surgical procedure, resection of the cystic bag was per-

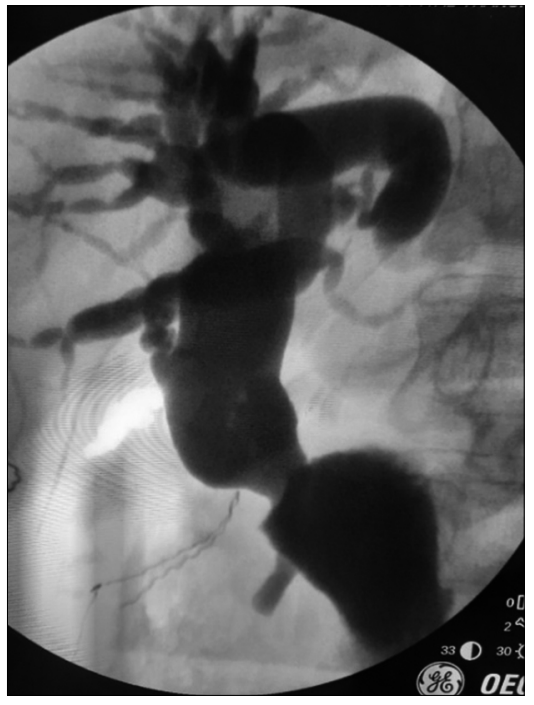

Fig. 3. Intraoperative Cholangiography. Bile duct dilatation comunicated with pseudocyst.

formed with closure of the stump and hepaticojejunalanastomosis in Roux en $\mathrm{Y}$ with transanastomotic intubation. The patient evolved favorably being discharged on the $7^{\text {th }}$ postoperative day. Thirty days after the operation a new CT scan was performed, showing a significant decrease in the size of the pseudocyst, going from $74 \mathrm{~mm}$ to $25 \mathrm{~mm}$ in the control and a reduction in the size of the duct of Wirsung from $13 \mathrm{~mm}$ to $3 \mathrm{~mm}$ in the control. Three months after surgery, the patient is asymptomatic and has recovered weight.

\section{DISCUSSION}

A pancreatic pseudocyst is a complication of pancreatitis of any etiology, around 20 to $40 \%$ of patients with chro- 
nic pancreatitis will develop a collection of these characteristics at some point in their evolution, about $30 \%$ of them will not require any treatment. They tend to settle more frequently in the body and pancreatic neck, the head of the organ being less affected. The pseudocyst can suffer complications such as infection, hemorrhage, free rupture to the abdominal cavity and fistulas. Of these complications, fistulization to neighbouring organs is the least frequent, the organs most affected are the stomach, duode- num and colon with less frequent problems in the esophagus and pleura. Fistula with the bile duct is extremely infrequent, with only 11 cases being counted until $1998^{4}$ and 19 cases until $2013^{1}$ (Table 1), our patient becomes case number 20 . Erosion of the wall of the bile duct would be produced by the tension of the pseudocyst and the consequent fistula. ${ }^{6}$ Of all the cases reported to date, the male sex was affected in an almost exclusive way, most with an age of over 50 years, which is coincident with the case

Table 1. Cases reported in the literature

\begin{tabular}{|c|c|c|c|c|c|}
\hline Author & Gender & Etiology & Symptoms & Treatment & Outcome \\
\hline León et al. ${ }^{1}$ & Female/71 years old & $\begin{array}{l}\text { Acute biliary } \\
\text { pancreatitis }\end{array}$ & Abdominal pain & $\begin{array}{l}\text { Kehr drainage+external } \\
\text { drainage of the PC }\end{array}$ & Discharged \\
\hline Al Ali et al. ${ }^{2}$ & Male/42 years old & $\begin{array}{l}\text { Alcoholic chronic } \\
\text { pancreatitis }\end{array}$ & $\begin{array}{l}\text { Abdominal } \\
\text { pain-jaundice }\end{array}$ & Endoscopic & Discharged \\
\hline DeVanna et al. $^{3}$ & Male/2 years old & $\begin{array}{l}\text { Cryptogenetic } \\
\text { acute pancreatitis }\end{array}$ & $\begin{array}{l}\text { Abdominal distention, } \\
\text { jaundice }\end{array}$ & Ascitis surgical drainage & Discharged \\
\hline Raimondo et al. ${ }^{4}$ & Female/69 years old & $\begin{array}{l}\text { Alcoholic chronic } \\
\text { pancreatitis }\end{array}$ & $\begin{array}{l}\text { Abdominal pain, } \\
\text { gastrointestinal } \\
\text { bleeding }\end{array}$ & Pancreatoduodenectomy & Death \\
\hline Hauptmann et al. $^{5}$ & Male/53 years old & $\begin{array}{l}\text { Alcoholic chronic } \\
\text { pancreatitis }\end{array}$ & $\begin{array}{l}\text { Abdominal pain, } \\
\text { fever, jaundice }\end{array}$ & $\begin{array}{l}\text { Percutaneous biliary } \\
\text { drainage }\end{array}$ & Discherged \\
\hline Carrere et al. ${ }^{6}$ & Male/74 years old & $\begin{array}{l}\text { Alcoholic chronic } \\
\text { pancreatitis }\end{array}$ & Abdominal pain & Endoscopic & Discharged \\
\hline Carrere et al. ${ }^{6}$ & Male/67 years old & $\begin{array}{l}\text { Alcoholic } \\
\text { pancreatitis }\end{array}$ & Abdominal pain, fever & $\begin{array}{l}\text { Biliary and pseudocys } \\
\text { jejunostomy }\end{array}$ & Discharged \\
\hline Carrere et al. ${ }^{6}$ & Male/65 years old & Acute pancreatitis & Abdominal pain & $\begin{array}{l}\text { Endoscopic failed-biliary } \\
\text { and pancreatic by pass }\end{array}$ & Unknow \\
\hline Skellenger et $\mathrm{al}^{7}$ & Male/47 years old & $\begin{array}{l}\text { Alcoholoc chronic } \\
\text { pancreatitis }\end{array}$ & $\begin{array}{l}\text { Abdominal pain, } \\
\text { jaundice, } \\
\text { GI bleeding }\end{array}$ & $\begin{array}{l}\mathrm{T} \text { tube with posterior } \\
\text { choledocoduodenostomy }\end{array}$ & Discharged \\
\hline Dalton et al. ${ }^{8}$ & Male/61 years old & $\begin{array}{l}\text { Alcoholic chronic } \\
\text { pancreatitis }\end{array}$ & Abdominal pain & Cyst-duodenostomy & Discharged \\
\hline Grace and Jordan ${ }^{9}$ & Unknown & Unknown & Unknown & Choledoco-duodenostomy & Unknow \\
\hline Sankaran and Walt ${ }^{10}$ & Unknown & $\begin{array}{l}\text { Alcoholic } \\
\text { pancreatitis }\end{array}$ & Unknown & Unknown & Unknow \\
\hline Gadacz et al. ${ }^{11}$ & Male/59 Years old & $\begin{array}{l}\text { Alcoholic chronic } \\
\text { pancreatitis }\end{array}$ & Abdominal pain & Pancreatoduodenectomy & death \\
\hline Gadacz et al. ${ }^{11}$ & Male/40 years old & $\begin{array}{l}\text { Alcoholic chronic } \\
\text { pancreatitis }\end{array}$ & Abdominal pain & $\begin{array}{l}\text { External drainage- } \\
\text { cholecistostomy }\end{array}$ & discharged \\
\hline Ellenbogen et al. ${ }^{12}$ & Male/54 years old & $\begin{array}{l}\text { Alcoholic chronic } \\
\text { pancreatitis }\end{array}$ & Abdominal pain & Cystojejunostomy & Unknow \\
\hline Bresler et al. ${ }^{13}$ & Male/66 years old & $\begin{array}{l}\text { Alcoholic chronic } \\
\text { pancreatitis }\end{array}$ & Abdominal pain & $\mathrm{T}$ tube choledocostomy & discharged \\
\hline Boulanger et $\mathrm{al}^{14}$ & Male/52 years old & $\begin{array}{l}\text { Alcoholic chronic } \\
\text { pancreatitis }\end{array}$ & Abdominal pain & Endoscopic & Discharged \\
\hline Ragunath et al. ${ }^{15}$ & Male/39 years old & Acute pancreatitis & $\begin{array}{l}\text { Bile leak thru the } \\
\text { external pseudocys } \\
\text { drainage }\end{array}$ & Endoscopic & Unknow \\
\hline Rickes et al. ${ }^{16}$ & Male/67 years old & $\begin{array}{l}\text { Alcoholic acute } \\
\text { pancreatitis }\end{array}$ & Abdominal pain & Endoscopic & Discharged \\
\hline Our cas & Male/58 years old & $\begin{array}{l}\text { Acute biliary } \\
\text { pancreatitis }\end{array}$ & $\begin{array}{l}\text { Abdominal pain, } \\
\text { jaundice, } \\
\text { weigt lose }\end{array}$ & $\begin{array}{l}\text { Bile duct resection with } \\
\text { hepaticojejunostomy }\end{array}$ & Discharged \\
\hline
\end{tabular}


presented. Pancreatitis of alcoholic origin was the most common origin of the pseudocyst, whereas pancreatitis of biliary origin was present only 2 times and coincidentally in two patients from South American countries where lithiasis was the most common origin of acute pancreatitis. The clinical symptoms of these patients have abdominal pain as the cardinal symptom, followed by jaundice. In our patient, these two symptoms were associated with significant weight loss. The literature coincides that the use of an ultrasound, tomography and MRCP are the ones that will make it possible to confirm the diagnosis not only of the pseudocyst but also to confirm the presence of a communication with the biliary tree; ERCP is another valuable study that had the advantage of being able to perform therapeutic gestures. Our case was studied with ultrasound, tomography and MRI, initially we suspected a compression of the bile duct due to its large dilation. The placement of a percutaneous bile drainage to improve liver function allowed us to perform a cholangiography to observe what we interpret as a saccular dilation of the extrahepatic bile duct communicated to the pseudocyst, the analysis of the extracted bile showed an amylase value greater than 20 thousand that justified communication, but also the possibility of a cystic dilation of the bile duct. Given this eventuality, surgical behaviour is decided to resolve biliary pathology and evaluate possible treatment for the pseudocyst. The finding of a hypoplastic gallbladder associated with a large dilatation of the extrahepatic bile duct with extremely thin walls as usually occurs in common bile duct cysts led us to perform a complete resection of the bile duct with a Roux-en-Y hepaticojejunostomy and a puncture and evacuation of the pseudocyst. ${ }^{17}$

From the bibliography consulted, most of the cases were resolved with surgical treatment, most of the procedures were a bypass and of the 12 patients treated with surgery, in 8 biliary drainage was performed, whether internal or external. In our patient, the lack of communication with the duct of Wirsung made an internal or external shunt of the pseudocyst unnecessary. Endoscopic treatment was used to a lesser extent, some of them required more than one procedure and in some, the patient required surgical treatment due to its failure. ${ }^{2,6}$ The percutaneous approach was used and successful with only one patient. There were 2 deaths within all of the patients reported and both were in pancreatoduodenectomies. Although the treatments are dissimilar and span over many years, we believe that it is likely that the treatment will depend a lot on 2 factors, the first of which is the possibility of mini-invasive procedures in the institution, the second is of the local characteristics of the pathology, it will be different if the fistula is from the pseudocyst into the bile duct without communication with the pancreatic duct than if the two systems (bile and pancreatic) are connected; in the first situation, the approach to the bile duct will resolve the fistula as it could be observed in cases where only internal or external biliary drainage was used. In the second situation, where both the bile duct and the duct of Wirsung are in communication with the pseudocyst, diversion of both the bile duct and the pseudocyst will be necessary. In our patient, the absence of communication with the pancreatic duct and the suspicion of the association of a common bile duct cyst induced us to perform the resection of the large cystic pouch and the preparation of a hepaticojejunostomy with very good subsequent evolution. Pancreatoduodenectomy as a treatment ${ }^{4}$ for the pseudocyst with a biliary fistula seems to us to be exaggerated despite the fact that its morbidity and mortality have currently decreased. ${ }^{18}$ Pathological anatomy reported findings compatible with congenital cystic dilatation of the bile duct. In this regard, it may be asked whether the patient actually had a common bile duct cyst with a probable Babit theory that justifies the reflux of pancreatic fluid into the bile duct or that the fistula from the pseudocyst has favored the passage of amylase to a normal bile duct during more than a year, with enzymatic activation and digestion, exercising the same pathophysiological pathway as if it had been congenital.

\section{ACKNOWLEDGEMENTS}

To miss Lucia Barquin for the translation of the text.

\section{CONFLICT OF INTEREST}

No conflict of interst and no funds received.

\section{ORCID}

Nari Gustavo: https://orcid.org/0000-0002-2559-5704

Lopez Alesio: https://orcid.org/0000-0001-8412-6265 
Romero Tanus Lorna: https://orcid.org/0000-0002-9679-8031

De Elias Eugenia: https://orcid.org/0000-0003-4619-4149

Lopez Flavia: https://orcid.org/0000-0003-2125-175X

\section{AUTHOR CONTRIBUTIONS}

Data recolection, figures editing: LA, DEE. Bibliographic search and selection: RTL, LF. Writing, review and editing: NG.

\section{REFERENCES}

1. León FF, Tapia VÁ, Avendaño RG. [Fistula formation between a pancreatic pseudocyst and the biliary tree]. Rev Chil Cir 2013;65:549-553. Spanish.

2. Al Ali JA, Chung H, Munk PL, Byrne MF. Pancreatic pseudocyst with fistula to the common bile duct resolved by combined biliary and pancreatic stenting--a case report and literature review. Can J Gastroenterol 2009;23:557-559.

3. DeVanna T, Dunne MG, Haney PJ. Fistulous communication of pseudocyst to the common bile duct: a complication of pancreatitis. Pediatr Radiol 1983;13:344-345.

4. Raimondo M, Ashby AM, York EA, Derfus GA, Farnell MB, Clain JE. Pancreatic pseudocyst with fistula to the common bile duct presenting with gastrointestinal bleeding. Dig Dis Sci 1998; 43:2622-2626.

5. Hauptmann EM, Wojtowycz M, Reichelderfer M, McDermott JC, Crummy AB. Pancreatic pseudocyst with fistula to the common bile duct: radiological diagnosis and management. Gastrointest Radiol 1992;17:151-153.

6. Carrere C, Heyries L, Barthet M, Bernard JP, Grimaud JC, Sahel J. Biliopancreatic fistulas complicating pancreatic pseudocysts: a report of three cases demonstrated by endoscopic retrograde cholangiopancreatography. Endoscopy 2001;33:91-94.
7. Skellenger ME, Patterson D, Foley NT, Jordan PH Jr. Cholestasis due to compression of the common bile duct by pancreatic pseudocysts. Am J Surg 1983;145:343-348.

8. Dalton WE, Lee HM, Williams GM, Hume DM. Pancreatic pseudocyst causing hemobilia and massive gastrointestinal hemorrhage. Am J Surg 1970;120:106-107.

9. Grace RR, Jordan PH Jr. Unresolved problems of pancreatic pseudocysts. Ann Surg 1976;184:16-21.

10. Sankaran S, Walt AJ. The natural and unnatural history of pancreatic pseudocysts. Br J Surg 1975;62:37-44.

11. Gadacz TR, Lillemoe K, Zinner M, Merrill W. Common bile duct complications of pancreatitis evaluation and treatment. Surgery 1983;93:235-242.

12. Ellenbogen KA, Cameron JL, Cocco AE, Gayler BW, Hutcheon DF. Fistulous communication of a pseudocyst with the common bile duct: demonstration by endoscopic retrograde cholangiopancreatography. Johns Hopkins Med J 1981;149:110-111.

13. Bresler L, Vidrequin A, Poussot D, Mangin P, Pinelli G, Boissel $\mathrm{P}$, et al. Fistulous communication of a pancreatic pseudocyst with the common bile duct: demonstration by operative cholangiogram. Am J Gastroenterol 1989;84:835-836.

14. Boulanger S, Volpe CM, Ullah A, Lindfield V, Doerr R. Pancreatic pseudocyst with biliary fistula: treatment with endoscopic internal drainage. South Med J 2001;94:347-349.

15. Ragunath K, Anagnostopoulos GK, Dunn K. Education and imaging. Hepatobiliary and pancreatic: choledochopancreatic fistula complicating acute pancreatitis. J Gastroenterol Hepatol 2006;21: 1753.

16. Rickes S, Mönkemüller K, Peitz U, Schinkel S, Kolfenbach S, Malfertheiner $\mathrm{P}$, et al. Sonographic diagnosis and endoscopic therapy of a biliopancreatic fistula complicating a pancreatic pseudocyst. Scand J Gastroenterol 2006;41:989-992.

17. Nari GA, Nassar M, Moreno E, Ponce O. Congenital cystic dilation of the biliary tract. Report on six patients. Cir Gen 2001; 23:168-172.

18. Nari G, Granero L, Silva J, Layún J, Mariot D, Duran N, et al. [Pancreatic fistula after pancreaticoduodenectomy. Pancreaticogastrostomy vs. pancreaticojejunostomy]. Rev Argent Cirug 2019;111: 79-89. Spanish. 